EWARYST KOWALCZYK

Uniwersytet im. Adama Mickiewicza w Poznaniu

\title{
ZAKAZ ALIENACJI DÓBR KOŚCIELNYCH INSTYTUCJI DOBROCZYNNYCH W CESARSTWIE RZYMSKIM
}

Treść: Wstęp. - 1. Zakazy alienacji dóbr instytucji dobroczynnych we wczesnym prawie kanonicznym. -2 . Zakaz alienacji majątku instytucji dobroczynnych w prawie rzymskim. -3 . Wnioski.

\section{Wstęp}

Pjęcie alienatio $^{1}$ w ścisłym znaczeniu dotyczyło w prawie rzymskim wszelkiego rodzaju przeniesienia własności ${ }^{2}$. Mogło być także rozumiane jako sprzedaż $\dot{z}^{3}$. Potoczne znaczenie tego słowa było jednak szersze i odnosiło się do jakiegokolwiek pozbycia się czegoś, oddalenia, usunięcia.

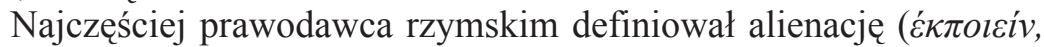
alienare $)^{4}$ poprzez wymienienie przykładów jej zastosowania: sprzedaż, darowizna, zamiana oraz ustanowienie emfiteuzy. Wyliczenie przykładów alienacji mieści się raczej w potocznym pojęciu tego słowa. Znajduje się bowiem wśród wymienionych przykładów emfiteuza, która polega na stanowieniu ograniczonego prawa rzeczowego na własności, a nie jej przeniesieniu. Należy pamiętać, że prawo do alienacji rzeczy stanowiło w rzymskim porządku prawnym jedno z podstawowych uprawnień właściciela.

Przedmiotem artykułu jest kwestia odstępstwa od reguły, czyli problem zakazów rozporządzania majątkiem kościelnych instytucji dobroczynnych. Należały do nich sierocińce, domy starców, domy

\footnotetext{
1 P. De Francisci, Il trasferimento della proprietà, Padova 1924, s. 103 i nast.

2 G. 2, 65; D. 5, 16, 28; CT. 3, 32 .

3 D. $4,7,8,2$; C. $5,71,18$.

4 Nov. 7; Nov. 120.
} 
ubogich czy chorych oraz schroniska pielgrzymów. Te oryginalne instytucje powstały w praktyce chrześcijańskiej IV wieku ${ }^{5}$, a od V wieku stały się tematem regulacji prawa kościelnego. Czasy rządów cesarzy chrześcijańskich spowodowały także objęcie instytucji dobroczynnych ustawodawstwem państwowym.

\section{Zakazy alienacji dóbr instytucji dobroczynnych we wczesnym prawie kanonicznym}

Alienacja dóbr kościelnych była, począwszy od V wieku, przedmiotem zakazów formułowanych we wczesnym Kościele ${ }^{6}$.

Pochodzący z 13 września 401 roku kanon synodu prowincjonalnego w Kartaginie ${ }^{7}$ wprowadzał zakaz sprzedaży czegokolwiek, co należy do Kościoła. Dopuszczano przy tym możliwość dokonania zbycia rzeczy w razie zaistnienia pilnej potrzeby, o ile rzecz kościelna nie przynosi dochodu. Sprawa powinna być wówczas przedłożona metropolicie prowincji i rozważona w określonym gronie biskupów. Jeśli pilna potrzeba zbycia rzeczy pojawiłaby się w jakimś kościele, który nie będzie miał możliwości zwrócenia się z kwestią do metropolity, wówczas należy przywołać grono biskupów z sąsiednich kościołów, którzy o prawidłowości transakcji będą mogli zaświadczyć przed synodem. W razie niezachowania powyższych wymogów dokonujący czynności będzie odpowiedzialny przez Bogiem, uznany za sprzedawcę dóbr kościelnych przez synod oraz pozbawiony urzędu.

5 W. ScHÖNFELD, Die Xenodochien in Italien und im Frankreich im frühen Mittelalter, ZSS Kan. Abt. 43, 12 (1922), s. 1-54; F. Boshof, Armenfürsorge im Frühmittelalter: xenodochium, marticula, hospitale pauperum, Vierteljahrschrift für Sozial- und Wirtschaftsgeschichte 71 (1984), s. 153-174; I. MILEWsKI, Rozwój chrześcijańskich instytucji dobroczynnych w zachodniej części Cesarstwa Rzymskiego w IV i V wieku, Przegląd Religioznawczy 4, 182 (1996), s. 1-15; J. NAumowicz, Instytucje charytatywne św. Bazylego, Vox Patrum 30-31 (1996), s. 125.

6 J. Gaudemet, L'Èglise dans l'Empire romain (IV-V siècles), t. III, Paris 1958, s. 310; W. BoJARsKi, Emfiteuza wedtug prawa rzymskiego, Torun 1970, s. 76.

7 Conc. Carth. c. 26, PL 67, 192: Ut res Ecclesiae nemo distrahat XXVI. Item placuit ut rem Ecclesiae nemo vendat: quod si redditus non habet, et aliqua nimia necessitas cogit, hanc insinuandam esse primati provinciae ipsius, ut cum statuto numero episcoporum utrum faciendum sit arbitretur. Quod si tanta urget necessitas Ecclesiae, ut non possit ante consulere, saltem vincios testes convocet episcopos, curans ad concilium omnes referre suae Ecclesiae necessitates: quod si non fecerit, reus Deo, et concilio venditor, honore amiss, teneatur. 
Kontynuację tegoż postanowienia stanowi jeden z kolejnych, pochodzący z 421 roku, kanon koncylium kartagińskiego ${ }^{8}$.Kanon zawiera zakaz (skierowany tym razem do prezbiterów) sprzedaży własności kościołów bez zgody biskupów. Postanowienie synodu powtarza także stanowisko, w myśl którego nielegalne jest sprzedawanie przez biskupów dóbr kościelnych bez konsultacji (lub zgody synodu) albo wiedzy ich prezbiterów. Postanowienie kościelne kończy się wymownym stwierdzeniem, iż tak jak biskup nie powinien przywłaszczać sobie własność Kościoła, który jest jego matką, tak prezbiter nie powinien czynić podobnie z majątkiem kościelnym, który oddany został pod jego pieczę.

Postanowienia synodu w Kartaginie stanowią wyraz jednoznacznej postawy władz Kościoła, zakazującej alienacji dóbr kościelnych poza wąsko zakreślonym wyjątkiem i pod pewnymi warunkami proceduralnymi. Prawo kanoniczne nie rozważało kwestii formy alienacji ani kategorii rzecz objętych zakazem. Wskazuje to, iż problem zbywania dóbr kościelnych miał znaczenie praktyczne.

Postanowienia synodu nie dotyczą wprost instytucji dobroczynnych. $\mathrm{O}$ ile jednak instytucje charytatywne stanowiły cześć majątku kościelnego, o tyle zakaz alienacji dotyczył także ich.

Zakaz alienacji dóbr kościelnych sformułowany został także na Zachodzie przez papieża Leona ${ }^{9}$ w liście napisanym 21 października roku konsulatu Kalepiusza, czyli w roku 447.

${ }^{8}$ Conc. Carth. c. 33, PL 67, 192-193: Ut presbyteri rem Ecclesiae in qua sunt constituti non vendant, et nulli episcopo liceat rem tituli matrcis Ecclesiae usurpare. XXXIII. Item placuit ut presbyteri non vendant rem Ecclesiae ubi sunt constituti, nescientibus episcopis suis, quomodo et episcopis non licet vendere praedia Ecclesiae, ignorante concilio, vel presbyteris suis. Non habente ergo necessitatem nec episcopo liceat matricis Ecclesiae, nec presbytero rem tituli sui usurpare (...).

9 Epist 17, PL 54, 727-729: Leo papa universis episcopis per Siciliam constitutis. Occasio specialum querelarum, curam nobis providentiae generalis indicit, ut quod in duabus provinciae vestrae Ecclesiis improbe gestum, injusteque praesumptum est, id constitutione perpetua ab omnium episcoporum usurpatione resecemus. Taurominitanis enim clericis Ecclesiae deplorantibus nuditatem, eo quod omnia ejus praedia, vendendo, donando, et diversis modis alienando, episcopus dissiparet; etiam Panormitani clerici, quibus nuper est ordinatus antistes, similem querimoniam in sancta synodo, cui praesidebamus, de usurpatione prioris episcopi detulerunt. Quamvis ergo jam ordinatum a nobis sit quemadmodum utriusque Ecclesiae utilitatibus consulatur, ne tamen hoc perniciosum nequissimae depraedationis exemplum cuiquam posthac fiat imitatible, hanc praecepti nostri formam apud dilectionem vestram volumus 
Leon, w liście skierowanym do wszystkich biskupów sycylijskich, wskazuje na okoliczności występowania ze skargami na nadużycia biskupów podczas sprawowania zarządu majątkiem kościelnym. Przywołuje przypadek kościoła w Tauromenium, którego duchowny o imieniu Panormus skarżył się przed świętym synodem na trwonienie przez biskupa majątku kościelnego. Nieuczciwy biskup miał sprzedawać dobra kościelne oraz rozporządzać nimi w inny sposób, narażając tym samym kościół na jeszcze większe zubożenie. Jak wskazuje pośrednio tekst listu, biskup został usunięty z urzędu, a na jego miejsce powołano nowego.

Ten $i$ inne podobne przypadki zmusiły Leona do roztoczenia szczególnej opieki nad wszystkimi kościołami i sformułowania wieczystego, dotyczącego wszystkich biskupów, zakazu darowania, zamiany lub sprzedaży jakiejkolwiek rzeczy będącej własnością jego kościoła (qua sine exceptione decernimus ut ne quis episcopus de Ecclesiae suae rebus audeat quidquam vel donare, vel commutare, vel vendere). Wyjątek stanowiła sytuacja, w której dokonanie takiej transakcji przyniosłoby niewatpliwą korzyść kościołowi. Wówczas biskup powinien skonsultować się i uzyskać zgodę pozostałych duchownych z jego kościoła. W razie wyrażenia zgody przez prezbitera, diakona lub duchownego jakiegokolwiek stopnia na dokonanie czynności przynoszącej szkodę kościołowi winnemu duchownemu wymierzona będzie kara w postaci pozbawienia urzędu oraz uniemożliwienia uczestnictwa w komunii świętej. Uzasadnieniem takiego rozstrzygnięcia jest przekonanie, że zarówno biskupi, jaki i duchowni niższych szczebli powinni dbać o interesy Kościoła i zachowywać nienaruszone dary przekazane w postaci swych majątków na rzecz Kościoła przez wiernych, w nadziei na zbawienie duszy.

esse perpetuam: qua sine exceptione decernimus ut ne quis episcopus de Ecclesiae suae rebus audeat quidquam vel donare, vel commutare, vel vendere; nisi forte ita aliquid horum faciat, ut meliora prospitiat, et cum totius cleri tractatu atque consensu id eligat, quod non sit dubium Ecclesiae profuturum. Nam praesbyteri, vel diaconi, aut cujuscumque ordinis clerici, qui conniventiam in Ecclesiae damna miscuerunt, sciant se et ordine et communione privandos: quia plenum justitiae est, fratres charissimi, ut non solum episcopi, sed etiam totius cleri studio, ecclesiasticae utilitatis incrementa serventur et eorum munera illibata permaneant, qui pro animorum suarum salute propriam substantiam Ecclesiis contulerunt. 
W treści zarządzenia papieskiego zwraca uwagę relacja o nadużyciach popełnianych przez biskupów, jako administratorów majątku kościelnego. Wskazane przypadki świadczą nie tyle o skali problemu, ale jego doniosłości w oczach Leona.

Papież Leon posługuje się także określeniami opisującymi sposoby alienacji dóbr kościelnych. Należy do nich darowizna, zamiana i sprzedaż (donatio, commutatio, venditio). Leon używa także określenia rozporzqdzać $w$ inny sposób (et diversis modis alienando). Terminy te stanowią wyraźne nawiązanie do prawnych form alienacji rzeczy. Być może ich wystapienie w pismach Leona wiązało się z pojawiającymi się kontrowersjami dotyczącymi rozumienia zakazu zbywania dóbr kościelnych.

Zarządzenie Leona wskazuje ponadto pośrednio, iż znaczna część majątku kościelnego pochodziła $\mathrm{z}$ rozporządzeń dokonywanych przez wiernych z pobudek religijnych. Niestety, brak w liście Leona wzmianki o instytucjach dobroczynnych.

Zarządzenia podobne do postanowień Leona sformułował także w 502 roku papież Symmachiusz ${ }^{10}$. Postanowienie papieża Symmachiusza wprowadzało zakaz alienacji (alienatio) rzymskich dóbr kościelnych, a w tym gruntów wiejskich i miejskich, wyposażenia kościołów czy naczyń liturgicznych. Zakaz obejmować miał rzeczy obecnie należące do Kościoła oraz te, które w przyszłości przezeń zostaną nabyte. Skierowany był do aktualnych przełożonych (qui nunc antistes), wybranych przez społeczność kościelną, a także do ich następców. W razie złamania zakazu czynność miała pozostać bezskuteczna (inefficax), a dokonujący jej oraz ci, którzy z nim współdziałali, narażeni byli na klątwę kościelną ${ }^{11}$.

${ }^{10}$ Epist. 6, źródło cyt. za C. Trezzini, La legislatione canonica di Pappa Gelasio I 492-496, Locarno 1911, s. 198: Ne unquam praedium seu rusticum sive urbanum, vel ornamenta et ministeria ecclesiarum, quae nunc sunt vel quae ex quibuslibet titulis ad ecclesiarum iura pervenerint, ab eo qui nunc antistes sub electione communi fuerit ordinandus, et illis, qui futuris saeculis sequentur, quosumque titulo atque commento alienentur. Si quis vero aliquid earum alienare voluerit, inefficax atque irritum iudicetur. Sitque facienti vel consentienti accipintique anathema.

11 Por. Grzegorz Wielki, Epist. 14, 2, CCL 140 A, 1066. 
Jak wynika z dalszej treści, postanowienie papieskie dotyczyć miało wszystkich rzymskich biskupstw (ecclesiarum per omnes Romanae civitatis titulos qui sunt presbyteri vel quicumque fuerint) ${ }^{12}$.

W kwestii alienacji dóbr kościelnych i na tle powyższych postanowień znamienny zdaje się przykład Ambrożego, który sprzedawał naczynia i szaty liturgiczne, by za uzyskane pieniądze wykupywać więźniów $^{13}$. Postawa Ambrożego stanowiła znaczący wyłom w ściśle pojmowanym zakazie alienacji dóbr kościelnych i wskazywała na rzeczywiste przeznaczenie majątku Kościoła, którego ważnym zadaniem miało być prowadzenie działalności dobroczynnej.

\section{Zakaz alienacji majątku instytucji dobroczynnych w prawie rzymskim}

Rozporządzanie rzeczami było w prawie rzymskim zasadniczo dozwolone. Wyjątkowo jednak istniały zakazy alienacji, dotyczące między innymi gruntu posagowego, nieruchomości małoletniego, rzeczy spornych czy rzeczy będących przedmiotem zapisu testamentowego ${ }^{14}$.

Zakaz alienacji został rozciagnięty w prawie poklasycznym na majątek Kościoła ${ }^{15}$. W tym miejscu należy przedstawić proces rozwoju regulacji w tym przedmiocie, gdyż stanowią one tło dla wprowadzanych równolegle norm dotyczących w szczególności instytucji dobroczynnych. Instytucje dobroczynne bowiem traktowane były jako część majątku kościelnego.

Zakaz rozporządzania dobrami kościelnymi wprowadzony został po raz pierwszy w 470 roku konstytucją Leona i Antemiusza ${ }^{16}$. Zakaz ten skierowany był jedynie do Kościoła (sacrosancta ecclesia) w Konstantynopolu i dotyczył należących do niego gruntów miejskich

12 Źródło cyt. za A. H. M. JonEs, Church finance in the fifth and the sixth centuries, Journal of Theologocal Studies 11 (1960), s. 89.

13 De off. 2, 28, PL 16, 139. Na temat działalności Ambrozego zob.: K. GuRDA, Wspomaganie ubogich $i$ potrzebujacych $w$ kościele mediolańskim za czasów św. Ambrożego, Vox Patrum 16 (1996), z. 30-31, s. 154-159.

${ }^{14}$ Codex Theodosianus (CT) 4, 5, 1; Codex Iustinianus (C.) 5, 13, 1, 15; C. 3, 2 a. Zob. P. Bonfante, Corso di diritto romano, t. IV, Milano 1930, s. 329 i nast.; M. Kaser, Das Römische Privatrecht, t. II, München 1971-1975, s. 188, 267.

15 T. S. Miller, The birth of the hospital in the Byzantine Empire, Baltimore 1985, Medical History 30 (1986), s. 103.

${ }^{16}$ C. $1,2,14$. 
i wiejskich i innych nieruchomości, a także niewolników, kolonów czy annonas civiles ${ }^{17}$.

W razie dokonania lub wyrażenia zgody przez arcybiskupa czy ekonoma zarządzającego majątkiem Kościoła na taką transakcję (na przykład z wdzięczności za dokonane wcześniej na rzecz Kościoła jakiegoś rozporządzenia majątkowego) czynność pozostawała nieważna. Zbyte rzeczy miały ulec zwrotowi, a nabywca miał zostać pozbawiony ceny kupna. W razie uzyskania przez ekonoma jakiejś korzyści z tytułu dokonanej czynności otrzymane przez niego rzeczy miały przypaść Kościołowi. Ponadto ekonom powinien być pozbawiony swej funkcji i zostać zobowiązanym do naprawienia szkody wyrządzonej Kościołowi. Wymownym jest fakt, iż obowiązek ten, w razie niewywiązania się ekonoma, przechodził na jego spadkobierców. Kara wygnania czekała natomiast notariuszy, którzy uczestniczyli przy sporządzaniu dokumentu transakcji ${ }^{18}$.

Uzasadnieniem tak surowego stanowiska było przekonanie prawodawcy, iż majątek kościelny, podobnie jak sam Kościół, powinien na zawsze pozostać nienaruszony ${ }^{19}$.

Omawiana konstytucja przewidywała jednak możliwość oddania dóbr (gruntów wiejskich i miejskich) kościelnych w użytkowanie (ususfructus $)^{20}$. Miało ono być ustanawiane albo na czas określony w pisemnej umowie przez strony, albo na czas życia biorącego w użytkowanie ${ }^{21}$.

Alienacji dóbr kościelnych dotyczyła także konstytucja Justyniana z 529 roku $^{22}$. Zakazywała ona zbywania i zastawiania (vel ad venditionem, vel hypothecam vel pignus trahere) naczyń i szat liturgicznych (sacratissima arcana vasa vel vestem) ${ }^{23}$. Podobnie jak w konstytucji

${ }_{17}$ W. BoJARSKI, op. cit., s. 76, przyjmuje za oczywisty fakt, że zakaz dotyczył także ustanawiania emfiteuzy na dobrach kościoła. Termin ecclesia jednak nie pojawia się w treści konstytucji.

18 C. $1,2,14,3-8$.

19 C. $1,2,14,2$.

20 C. $1,2,14,9$.

21 J. L. Murga, Los negocios “pietatis causa” en las constitutiones imperiales postclassicas, AHDE 37 (1967), s. 319.

22 C. 1, 2, 21.

23 Naczynia i szaty liturgiczne (także w okresie chrześcijańskim) traktowane były, zgodnie z klasycznymi wymogami, jako rzecz święte, a przez to extra commercium. I. $2,1,8$. 
Leona i Antemiusza, w razie dokonania zakazanej czynności, przedmioty liturgiczne powinny zostać zwrócone, chyba że uległy zniszczeniu lub zostały stracone.

Justynian przewidział także wyjątek od powyższego zakazu: przedmioty liturgiczne mogły zostać zbyte lub zastawione w celu uzyskania środków na wykup więźniów ${ }^{24}$. Reguła ta powtarzana była jeszcze kilka razy w kolejnych konstytucjach Justyniana ${ }^{25}$.

Postanowienia dotyczące majątku Kościoła w Konstantynopolu zostały rozwinięte przez cesarza Justyniana w 530 roku $^{26}$. Justynian zakazywał oddawania rzeczy należących do Kościoła w dzierżawę na podstawie prawa kolonatu (ius colonarium) ${ }^{27}$. Postanowienia konstytucji dotyczą ponadto możliwości ustanawiania emfiteuzy na dobrach kościelnych. Zgodnie z postanowieniem prawodawcy możliwe było oddawanie gruntów należących do Kościoła w dzierżawę wieczystą na 20 lat, najwyżej na czas życia emfiteuty (który musiał być osoba bogata) i jego dwóch następców ${ }^{28}$.

W 537 roku $^{29}$ Justynian wprowadził zakaz ustanawiania emfiteuzy wieczystej na dobrach Wielkiego Kościoła w Konstantynopolu. Zezwolił jednak na ustanawianie emfiteuzy wieczystej pomiędzy po-

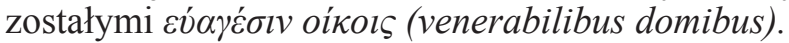

Konstytucja Anastazjusza [C. 1, 2, 17]. Od czasów rządów Anastazjusza (491-518) rozpoczyna się także okres regulowania możliwości alienacji dóbr należących do instytucji dobroczynnych. Większość aktów prawnych w tej materii odnosić się będzie zarówno do majątku kościołów, jak i samych instytucji dobroczynnych, niektóre zaś skierowane będą wyłącznie do tych drugich.

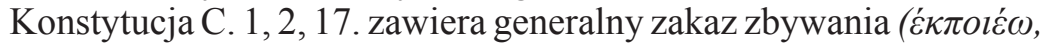
alienationem cessare) należących do nich nieruchomości ( $\pi \rho \alpha \gamma \mu \alpha ́ \tau \omega v$

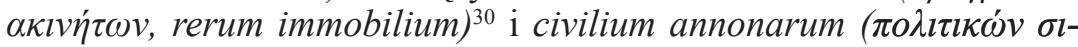
$\tau \eta \rho \varepsilon \sigma i \omega v)$. Jednak Anastazjusz przewidział także możliwość sprze-

${ }^{24}$ C. $1,2,21,2$.

25 I. 1, 2, 8; Nov. 7, 8; Nov. 120, 10.

${ }^{26}$ C. $1,2,24$.

27 C. $1,2,24,1$.

28 C. 1, 2, 24, 3-4.

29 Nov. 55.

30 Postanowienia konstytucji nie dotyczyły rzeczy ruchomych, z wyjątkiem naczyń liturgicznych (vasa sacra); C. 1, 2, 17, 5 . 
daży, ustanowienia hipoteki lub emfiteuzy albo dokonania zamiany wymienionych dóbr. Uzasadnieniem dla takich czynności mogła być konieczność przeznaczenia uzyskanej ceny kupna lub pożyczki pod zastaw na umorzenie długów (które przeszły na kościół lub instytucję dobroczynna przy okazji dokonania na ich rzecz rozporządzenia testamentowego) na potrzeby Kościoła, wykupienie sprzedanych obiektów albo odbudowę świątyni. Zamiana mogła być dokonywana tylko w razie konieczności, a rzecz, której kościół lub instytucja się pozbywały, miała przynosić mniejsze korzyści niż rzecz uzyskana na skutek zamiany. Oddane w emfiteuzę mogły być jedynie grunty, które, ze względu na swą jałowość, przynosiły szkody. W tym ostatnim przypadku prawodawca przewidział także możliwość darowania gruntu ${ }^{31}$.

W razie dokonania czynności wbrew zakazowi, bez uzasadnienia albo z zaniedbaniem formalności, zarówno pożyczkodawca, jak i kupujący powinni stracić rzecz, a także odpowiednio kwotę pożyczki lub cenę kupna. Dokonujący z kościołem albo z instytucją dobroczynną zamiany powinien stracić rzecz własną oraz tę, którą uzyskał. Podobnie ktokolwiek otrzymujący od Kościoła w dzierżawę wieczystą, w darowiźnie albo na podstawie innego tytułu jakąkolwiek rzecz wbrew zakazom, powinien otrzymaną rzecz zwrócić ${ }^{32}$.

Konstytucja Justyniana z 528 roku [C. 1, 3, 41 (42)]. Kolejne regulacje $\mathrm{w}$ materii alienacji dóbr instytucji dobroczynnych pochodzą już od Justyniana.

Konstytucja Justniana C. 1, 3, 41 (42). zawiera regulacje dotyczące zarządu majątkiem kościelnym, skierowane do biskupów, ekonomów i administratorów instytucji dobroczynnych. Część przepisów dotyczy wyłącznie majątku kościoła biskupiego, część majątku instytucji

${ }^{31}$ Dokonanie dozwolonych czynności musiało spełniać określone wymogi formalne. Sprzedaż, zamiana, ustanowienie hipoteki lub emifetuzy i zapewne darowizna musiały być dokonane $\mathrm{z}$ formie pisemnej z podaniem przyczyn dokonania czynności i wskazaniem obecnych przy transakcji. Umowa sporządzona na terenie Bizancjum

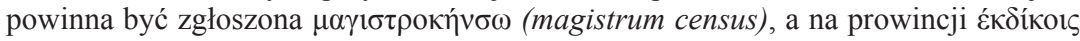
(defensores) na podstawie stosownych dokumentów kościelnych, w obecności ekonoma kościelnego i duchownych, w przypadku klasztoru w obecności opata i mnichów, a w przypadku ptochium i sierocińców w obecności administratora i podległego mu personelu, który w większości musiał wyrazić na dokonanie czynności zgodę. Zawarciu umowy towarzyszyć powinna ponadto zgoda biskupa właściwego ze względu na miejsce dokonania transakcji.

32 C. $1,2,17,3$. 
dobroczynnych. Pozostałe regulacje skierowane są do obu rodzajów majątków ${ }^{33}$. Celem wydania tej konstytucji była ochrona majątku kościelnego i instytucji dobroczynnych oraz przeciwstawienie się nadużyciom ze strony nieuczciwych zarządców. Zasadniczą kwestią było odróżnienie majątku zarządcy i majątku instytucji oraz zachowanie tego ostatniego przed uszczupleniem ${ }^{34}$.

W myśl konstytucji Justyniana przełożony instytucji dobroczynnej nie mógł rozporządzać majątkiem, jaki nabył po objęciu swej funkcji. Dobra te przypadały instytucji, którą zarządzał, i przeznaczone były na cele dobroczynne ${ }^{35}$. Mógł natomiast w pełni dysponować w tym czasie majątkiem, jaki posiadał przed swą nominacją lub tym, jaki $\mathrm{w}$ trakcie pełnienia funkcji przełożonego otrzymał od rodziców, stryjostwa, braci czy sióstr ${ }^{36}$.

Dla tych, którzy nie przestrzegali zakazu, prawodawca przewidział określone sankcje. Wprawdzie przy okazji administratorów instytucji dobroczynnych nie ma mowy o karach, lecz jedynie zawarta jest naganna ocena niewłaściwego postępowania ${ }^{37}$, jednak można, jak zauważa F. Fabbrini ${ }^{38}$, przyjąć, że dotyczyły ich także postanowienia skierowane do ekonomów ${ }^{39}$. Zgodnie z tymi postanowieniami nieuczciwy zarządca zobowiązany był do wyrównania spowodowanych przez siebie strat.

Postanowienia, dotyczące zakazu alienacji dóbr uzyskanych przez administratora instytucji dobroczynnej, zostały powtórzone w $534 \mathrm{r}^{40}$ Justynian upoważnił przełożonych do dysponowania nabytym po

33 P. W. Duff, Personality in the Roman Private Law, Cambridge 1938, s. 191.

34 F. FABBrini, La personnalità giuridica degli enti di assistenza (detti "piae causae”) in diritto romano, [w:] Apollinaris. Comantarius Juris canonici, t. 63, Roma 1990, s. 92; A. PhilipsBorn, Les établissements charitables et les théories de la personalité juridique le droit romain, RIDA 6 (1951), s. 146.

35 C. 1, 3, 41 (42), 12.

${ }^{36}$ Nabycie to nie musiało ograniczać się do nabycia spadku, lecz polegać mogło także na otrzymaniu darowizny. C. 1, 3, 41 (42), 11.

37 C. 1, 3, 41 (42), 14.

38 F. FABBRINI, op. cit., s. 93-94.

39 C. 1, 3, 41 (42), 10.

40 Nov. 131, 13. 
objęciu urzędu majątkiem tylko na cele dobroczynne lub związane $\mathrm{z}$ funkcjonowaniem samej instytucji $\mathrm{i}^{41}$.

Konstytucja Justyniana z 530 roku [C. 1, 3, 45 (46)]. W 530 roku w Konstantynopolu wydana została kolejna konstytucja w omawianej materii. Konstytucja C. 1, 3, 45 (46) adresowana do praefectus praetorio Juliana dotyczyła w zasadniczej części tworzenia instytucji dobroczynnych w drodze czynności mortis causa.

Konstytucja omawiała sytuację, w której ktoś zostawi (w testamencie) albo w darowiźnie duchowieństwu, mnichom, diakonisom, ptochium, ksenonowi, nosokomium, brefotrofium kościołowi, biednym albo innej instytucji dobroczynnej lub innemu podobnemu stowarzyszeniu roczny legat czyli42.

Zgodnie z postanowieniami konstytucji członkowie takiej instytucji nie mogli nabywać od niej dóbr zapisanych w rocznym legacie. $\mathrm{W}$ razie zwarcia takiej transakcji narażeni byli na stratę uzyskanych przedmiotów, natomiast sama umowa była nieważna ${ }^{43}$. Jak wskazuje dalsza część konstytucji, otrzymane w rocznym zapisie dobra nie mogły stanowić przedmiotu obrotu prawnego, gdyż powinny jako zachowane świadczyć o szczodrobliwości spadkodawcy ${ }^{44}$. Przełożony instytucji upoważniony był do dochodzenia od osoby, która zawarła niedozwoloną umowę kupna, zwrotu rzeczy, a przysługujące mu z tego tytułu roszczenie nie ulegało przedawnieniu ${ }^{45}$.

Problematyka obrotu dobrami otrzymanymi w drodze zapisów, a w tym rocznych legatów na rzecz instytucji dobroczynnych, powtórzona została w konstytucji C. 1, 3,55 (57) z 534 roku oraz noweli 131 z 545 roku. Uczynił jednak wyjątek dla sytuacji, w której instytucji dobroczynna znajduje się daleko ${ }^{46}$. Wówczas instytucja mogła sprze-

${ }^{41}$ J-U. Krause, Witwen und Waisen in Römischen Reich, t. IV, Stuttgart, 19941995, s. 33-37; T. Kunderewicz, Disposizioni testamentaire e donazioni a scopo di beneficenza nell diritto giustinianeo, SDHI 47 (1981), s. 62; P. W. DuFF, op. cit., s. 191; S. Longosz, Ksenodochium - hospicjum wczesnochrześcijańskie, Vox Patrum 30-31 (1996), s. 323.

${ }^{42}$ Zapis, zgodnie z którym zapisobiorca otrzymywał rocznie określoną sumę pieniędzy lub określoną ilość rzeczy przez pewien czas lub dożywotnio.

${ }^{43}$ C. 1, 3, 45 (46), 11.

${ }_{44}$ C. 1, 3, 45 (46), 10.

${ }_{45}$ C. 1, 3, 45 (46), 11.

46 Nov. 131, 12. 
dać legat lub dokonać jego zamiany za nieruchomości znajdujące się blisko niej.

Nowela Justyniana z 535 roku [Nov. 7]. Próbę kompleksowego uregulowania kwestii obrotu majątkiem instytucji dobroczynnych stanowi nowela z 535 roku [Nov. 7]. Justynian powołał się w niej na wcześniejsze regulacje Leona [C. 1, 2, 14] z 470 roku oraz Anastazjusza [C. 1, 2, 17]. Prawodawca przypomniał, że konstytucje tych cesarzy odnosiły się do Kościoła (w przypadku konstytucji Leona) oraz dodatkowo instytucji dobroczynnych (w przypadku konstytucji Anastazjusza), znajdujących się wyłącznie w Konstantynopolu. Pomimo wyrażonego szacunku dla swych poprzedników ${ }^{47}$ uznał wcześniejsze regulacje za niedoskonałe i ograniczone oraz wymagające uzupełnienia i poprawek $^{48}$.

Po zreferowaniu postanowień swych poprzedników Justynian przeszedł do stwierdzenia, że zaistniały liczne przypadki obchodzenia zakazów alienacji dóbr kościelnych, głównie przy zastosowaniu prawa kolonatu czy emfiteuzy ${ }^{49}$.

Justynian wskazywał w swej konstytucji, że kościoły i instytucje dobroczynne powinny mieć pozwolenie na zbywanie lub zastawianie należących do nich rzeczy. Wśród adresatów tej normy prawodawca szczegółowo wymienił: kościół stołeczny i kościoły od niego zależne, także te znajdujące się w prowincjach i podległe tam istniejącym patriarchatom albo arcybiskupstwom (Wschodu, Illirii, Egiptu, Libii, Afryki i innych). Postanowienia noweli skierowane były także do prawowiernych biskupów zachodnich, a także wszelkich przełożonych ksenodochiów, ptochotrofiów, nosokomiów, orfanotrofiów, gerontocomiów, brefotrofiów, opatów i przełożonych klasztorów żeńskich,

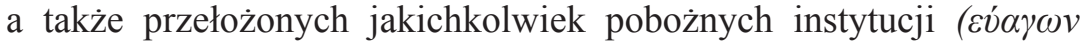

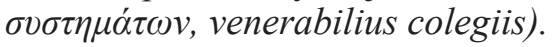

47 Głównie wobec Leona, którego Justynian przyrównał do najświetniejszego, jego zdaniem, cesarza chrześcijańskiego, Konstantyna. Justynian stwierdził, że cesarz Leona wzmocnił znaczenie Kościoła i zabezpieczył jego majątek. [Nov. 7 pr.].

48 Zgodnie z intencją wyrażoną przez Justyniana na wstępie noweli, udoskonalenie, rozjaśnienie i uporządkowanie ustawodawstwa leżało u podstaw wszelkiej jego działalności prawodawczej [Nov. 7 pr.]. Podobna deklaracja znajduje się na wstępie noweli 120.

49 Nov. 7 pr. 1. 
Zakaz alienacji bez pozwolenia dotyczył nieruchomości w postaci budynków, gruntów, ogrodów i tym podobnych, a także niewolników wiejskich oraz civile annonam, należacych do wymienionych instytucji.

Wobec przypadków alienacji dóbr kościelnych już dokonanych Justynian, ze względu na szczególne trudności w ewentualnym badaniu dokumentacji czynności, zadecydował nie stosować postanowień swej konstytucji. To, co już zostało dokonane, miało pozostać niezmienione, natomiast próby alienacji w przyszłości miały być surowo karane.

Nowela Justyniana z 544 roku [Nov. 120]. W 544 roku kwestia zakazu alienacji dóbr kościelnych stała się ponownie przedmiotem regulacji cesarskiej. Nowela 120. Justyniana skierowana była do praefecto praetorio Petro i dotyczyła Kościoła i instytucji dobroczynnych znajdujących się na terenie Konstantynopola, z wyjątkiem klasztorów ${ }^{50}$. Justynian deklaruje, że wydana nowela ma być zebraniem dotychczasowego ustawodawstwa w sprawie sprzedaży rzeczy kościelnych, ustanawiania dzierżawy i emfiteuzy oraz w kwestii zarządu tym majątkiem.

Prawodawca potwierdza generalny zakaz sprzedaży, darowania, zamiany, ofiarowania $\mathrm{w}$ jakikolwiek sposób, oddawania w prawo kolonatu albo jakiegokolwiek zbywania rzeczy należących do kościoła konstantynopolitańskiego, orfanotrofium, nosokomium, ksenodochium, ptochotrofium albo innej pobożnej instytucji, która znajduje się w stolicy albo jej okręgu.

Bezwzględnemu zakazowi alienacji dóbr instytucji dobroczynnych podlegała sprzedaż, ustanowienie emfiteuzy czy hipoteki na nieruchomościach instytucji dobroczynnej na rzecz przełożonych, ekonomów, chartularii, a także ich dzieci i rodziców oraz innych osób z nimi spokrewnionych lub spowinowaconych. W razie dokonania takiej czynności, osobiście lub przez osoby podstawione, umowa traktowana była jako nieważna (irritum fore), a cały majątek stron takiej czynności (nabywcy oraz przełożonego lub innej osoby zarządzającej majątkiem instytucji dobroczynnej) przechodził po jego śmierci na rzecz instytucji, od której rzecz (lub prawo) została nabyta ${ }^{51}$. Postanowienia

\footnotetext{
50 Nov. 120.

51 Por. Nov. 120, 5, 1.
} 
te miały także zastosowanie do instytucji dobroczynnych położonych poza Konstantynopolem ${ }^{52}$.

Dwa lata później, czyli w 546 roku, Justynian zezwolił na ustanawianie emfiteuzy na rzecz przełożonych lub duchownych na gruntach przylegających do budynków kościelnych i innych venerabilium domuum $^{53}$. Na dokonanie takiej czynności zgodę musieli wyrazić wszyscy duchowni danego kościoła. Zdaje się jednak, że przepis ten dotyczył tyko kościołów i klasztorów (W. Bojarski ${ }^{54}$ ), a nie instytucji dobroczynnych (H. R. Hagemann ${ }^{55}$ ), które nie są w noweli 123 wymieniane.

Zakaz alienacji dotyczył też bezwzględnie dóbr, które instytucja dobroczynna otrzymała od cesarza ${ }^{56}$.

W 545 roku pojawił się kolejny zakaz dotyczący alienacji dóbr należących do instytucji dobroczynnej. Przewidywał on, że heretykowi nie można oddawać w dzierżawę, emfiteuzę, sprzedawać albo przekazywać w inny sposób rzeczy należących do kościoła albo instytucji dobroczynnej. W razie naruszenia tego zakazu heretyk tracił tak nabyta rzecz na rzecz instytucji, a jej przełożony był pozbawiony swej funkcji, a ponadto był umieszczany w klasztorze i przez rok pozbawiony uczestnictwa w komunii świętej ${ }^{57}$.

\section{Wnioski}

Zakaz alienacji dóbr kościelnych, a w tym instytucji dobroczynnych, był wyrazem szczególnego zainteresowania prawodawcy istnieniem i funkcjonowaniem instytucji dobroczynnych. Całość postanowień cesarskich zmierzała wyraźnie do ochrony majątku kościelnego przed uszczupleniem ze strony nieuczciwych kontrahentów oraz przełożonych. Obszar działalności Kościoła i instytucji dobroczynnych stanowił szczególne „miejsce spotkania się" interesu prywatnego właściciela oraz interesu publicznego. Zgodnie z prawem uprawnienia właścicielskie przewidywały możliwość rozporządzania majątkiem, jednak interes publiczny reprezentowany najpierw przez władze ko-

\footnotetext{
${ }^{52}$ Nov. $120,7,1$.

53 Nov. 123, 6.

54 Op. cit., s.80.

55 Die Stellung der piae causae nach Justinianischen Recht, Basel 1953, s. 56.

56 Nov. 120, 5.

57 Nov. 131, 14.
} 
ścielne, potem przez prawodawcę stanowił w tej mierze ograniczenia. Można rzec, że prawo rzymskie stało na straży trwałości kościelnych instytucji dobroczynnych, zgodnie z zasada, że pomyślność religii chrześcijańskiej gwarantuje pomyślność samego imperium ${ }^{58}$.

The prohibition of alienation of ecclesiastical charitable institutions' property in

\section{Roman Empire}

The subject of the submission are the prohibitions of alienations of Christian charitable institutions` estates. Christian charitable institutions came into being in $4^{\text {th }}$ Century. The charitable institutions displayed a new way of charitable activity to advantage.

The charitable institutions became the matter of ecclesiastical legal regulation in $5^{\text {th }}$ Century. Some of those regulations concerned interdictions of sale, donations, lend, lease or any disposal of Church and its institutions' property.

The prohibition of alienation indicated that the imperial legislation was focused on well existence and functioning of ecclesiastical charitable institutions. The aim of imperial legislation was the protection of ecclesiastical property from diminution by the acts of fraud conducted by dishonest clergy or contracting party. According to Roman legal tradition the owner was permitted to alienate his property. But by the cause of public benefit ecclesiastical and imperial authorities enforced limitation of this owner's right. Now, we can say, that the existing and activity of charitable institutions was a sphere of privet and public interests.

58 Nov. 109 pr. 